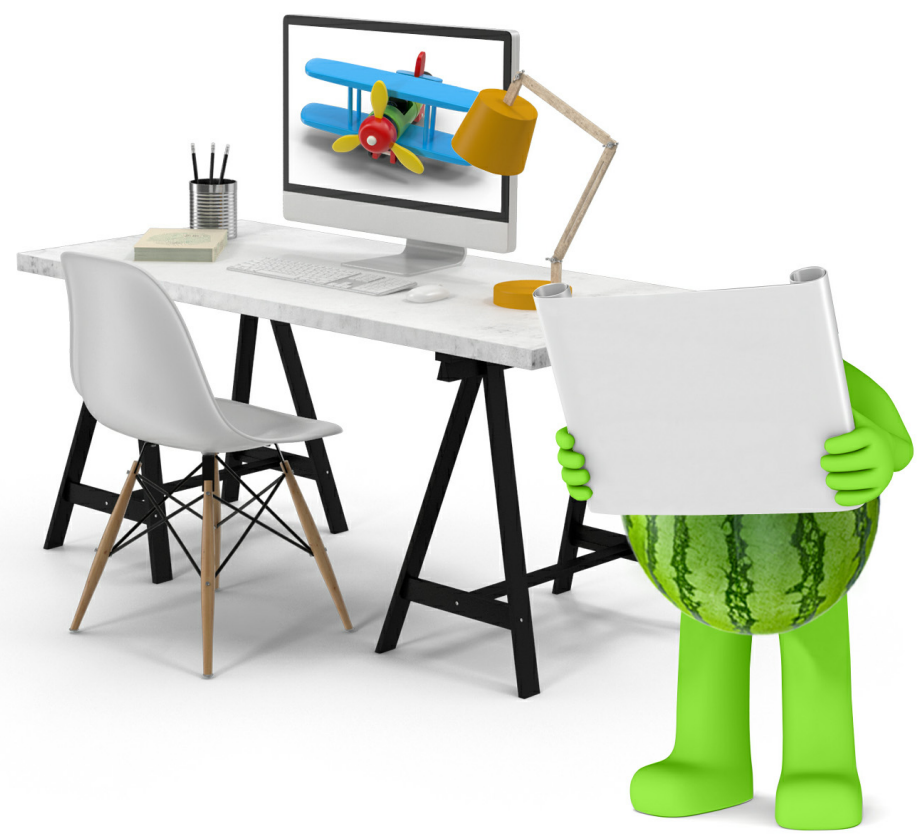

\title{
MULTIDISCIPLINARY PROJECT OF HISTORICAL AIRCRAFT VIRTUAL RECONSTRUCTIONS AS A WAY OF POPULARIZING SCIENCE
}




\title{
Sciendo
}

\section{MULTIDISCIPLINARY PROJECT OF HISTORICAL AIRCRAFT VIRTUAL RECONSTRUCTIONS AS A WAY OF POPULARIZING SCIENCE}

\author{
Dr hab. inż. Krzysztof Szafran \\ Lukasiewicz Research Network - Institute of Aviation, Warsaw, Poland \\ krzysztof.szafran@ilot.edu.pl •ORCID 0000-0003-3974-1466 \\ Ireneusz Kramarski \\ HORNET, Nowy Dwór Mazowiecki, Poland \\ irek@kramarski.com.pl • ORCID 0000-0001-9525-7877 \\ DOI: 10.2478/minib-2019-0051
}

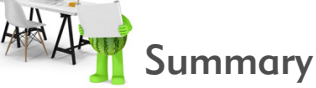

Research and development institutions have a wide range of competences in their fields of scientific and technical activity. They also often have some unique capabilities to do research and development (R\&D). However, these possibilities are often known only to a small group of industry specialists and few parliamentary representatives. There is also a lack of information about research capabilities of R\&D institutes in industry, especially among small and medium enterprises.

The aim of the article is to present the concept of a multidisciplinary research project aimed at testing by a scientific research institution the possibility of using social media and modern techniques of visualization and computer simulation in aircraft reconstruction engineering. The authors propose to try the approach of marketing campaign capabilities of research and development institutions in a way similar to the action of raising funds for some purpose, but unlike this type of action, the campaign should be aimed at increasing technical awareness of the society. As part of the pilot program, the authors propose a virtual reconstruction of the construction of the Polish PZL P-50 Jastrzab fighter plane whose two prototypes were created before the outbreak of World War II. On the basis of analyses, calculations and computer simulations, in the second phase it is proposed to make a preliminary design of the aircraft with performance similar to the PZL P-50 on the basis of modern knowledge and the latest technologies available in aviation technology. One of the ways to encourage people to undertake creative work, including the restoration of historical objects, will allow them to gain valuable employment possibilities in R\&D institute [19].

The combination of marketing techniques, using the power of social media, with the strictly engineering challenges of recreating a historic aircraft and designing its modern equivalent, gives the possibility to confirm the technical and organizational capabilities of the research and development institutions. On the basis of the above activities, a database of people interested in research and development activities of scientific institutions and their contribution to the reconstruction of historically important products of Polish technical thought will be built. 



\section{Introduction}

In order to popularize aviation science and technology, mass events are organized, which showcase modern and historical aircraft constructions. However, due to the war damage in Poland we have only single copies of the types of aircraft operated and produced in the interwar period, i.e. in the years 1918-1939. Besides, archival construction documentation is rare, and even photo documentation of aircraft created just before the outbreak of World War II is very limited. In the last decade, a model of a bomber PZL-37B Łoś was created, which is presented in the Museum of Polish Aviation in Kraków [17]. However, there are many other, no less interesting, aircraft constructions waiting to be reconstructed, such as the observation plane LWS-3 Mewa, the light bomber PZL-46 Sum, the advanced trainer PWS-33 Wyżeł, the twin-engine fighter plane PZL P-38 Wilk or the fighter plane PZL-50 Jastrząb which already existed in the form of flying prototypes.

\section{Figure 1. Fighter plane PZL P-50 Jastrzqb — visualization [6]}

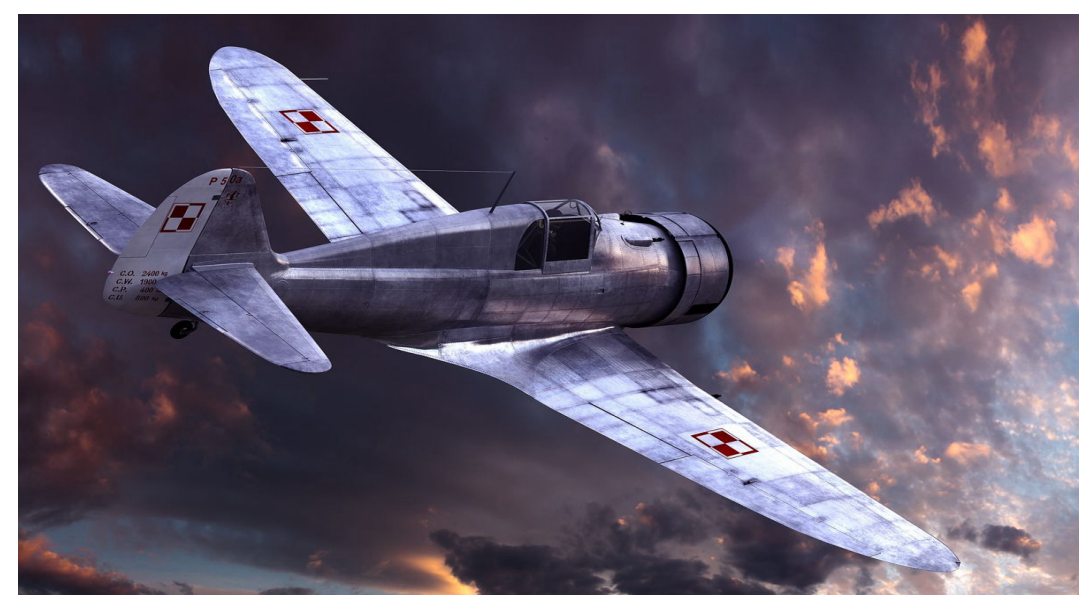

The authors, therefore, propose to launch a multidisciplinary research project aimed at testing the possibility of using social media and modern visualization and computer simulation techniques in the engineering of the reconstruction of the PZL-50 Jastrząb aircraft (Fig. 1). An additional 
bonus of the project may be the creation of a rare model of this aircraft to be exhibited in the Polish Aviation Museum in Krakow. Scientific and research institutions participating in the project may show their capabilities in selected technical fields, which will be used for marketing purposes in Poland and abroad. The progress will be presented on a dedicated website and during air shows and other mass events in the form of already created fragments of the model and posters. It is also proposed to perform full mass calculations, performances, stability and control characteristics the aircraft, testing in a virtual wind tunnel, comparing the performance with other aircraft of that period, which will enrich the knowledge of aviation technology in the Republic of Poland in the 1930s.

Comprehensive marketing activities of the research and development institutions participating in the project and the related revenues from commissioned work may finance a flying real size replika of the PZL-50 Jastrząb airplane, which could become an exceptionally interesting aircraft at air shows in Poland and abroad. Positive results of the multidisciplinary research project will allow us to work on the reconstruction of historical aircraft.

At the same time, we should observe significant changes in the realization and financing business activities related to the increasing use of the global Internet and the rapid grow of social media (Facebook, Twitter, Instagram, YouTube, etc.). On the basis of social media, methods of financing new projects have developed in the form of social financing (crowdfunding) and community cooperation (crowdsourcing). Therefore, the authors see opportunities to use in particular the principles of crowdsourcing in the marketing of research and development institutions in the implementation of the project to restore the historic Polish aircraft, on the example of the PZL P-50 Jastrząb fighter plane.

\section{Fighter plane the PZL P-50}

In the mid 1930s, after partially overcoming the effects of the global economic crisis, Poland returned to the construction of new aircraft for defence purposes. Within the framework of new development 
programmes, a modern bomber PZL-37B Łoś, a light bomber PZL-46 Sum, an observation plane LWS-3 Mewa, a twin-engine fighter PZL P-38 Wilk and an advanced trainer PWS-33 Wyżeł to train pilots of multiengine machines [1], [2], [5], [7].

At that time, in Great Britain, the Supermarine Spitfire and Hawker Hurricane fighter planes were put into serial production, in France the Morane-Saulier MS-406 and Dewoitine 530 fighters, in Italy the Fiat G50 and Macchi MC-200 planes were put into serial production and in Germany it was decided to develop only one fighter, which was Messerschmitt Bf-109 (later referred to as Me-109).

However, in Poland the work on a modern fighter (chaser) was delayed. The PZL P-24 aircraft was constructed, which was the culmination of the development line of the Pulaski winged aircraft (from P-1 to P-11) and was characterized by strong weaponry $(2 \times 7,62 \mathrm{~mm}$ machine guns and $2 \times 20 \mathrm{~mm}$ cannons) and good performance, as for an airplane with a fixed undercarriage. However, the P-24 was produced only for export (Bulgaria, Greece, Romania, Turkey), because it was decided to introduce a new fighter aircraft with much higher performance in the low-pass system with retractable landing gear to the Polish military aviation inventory.

In 1936 in Polskie Zakłady Lotnicze (Polish Aircraft Factories) a project of a fighter plane PZL-50 Jastrząb underthe direction of engineer Wsiewołod Jakimiuk was started (Fig. 2). The first prototype was completed in October 1938 and after the ground tests it was first flown in February 1939. Due to the insufficient engine power, resulting from a faulty cooling system, the aircraft developed a maximum speed of only 420-430 kph (only as much as PZL P-24 with a fixed undercarriage), and was characterized by a worse agility in comparison to the aircraft with the Pulaski wing. 
Figure 2. The first prototype of the PZL P-50 Jastrzqb

fighter plane in 3-view [1]

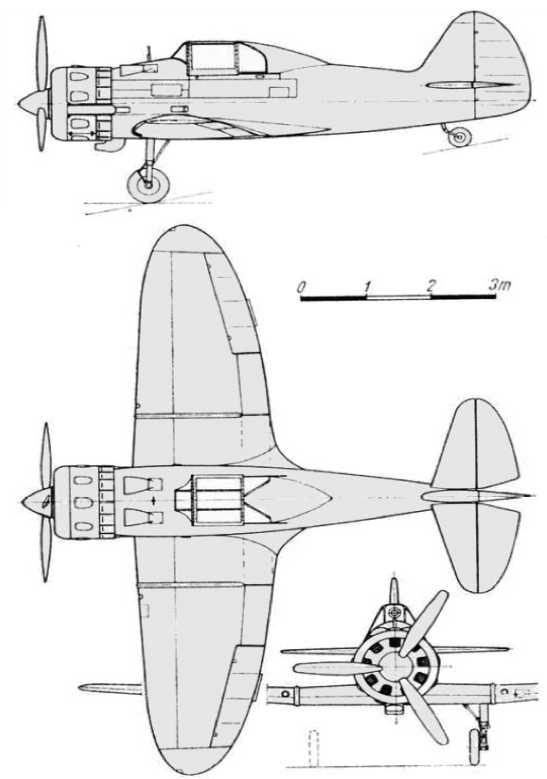

In 1936 in Polskie Zakłady Lotnicze (Polish Aircraft Factories) a project of a fighter plane PZL-50 Jastrząb underthe direction of engineer Wsiewołod Jakimiuk was started (Fig. 2). The first prototype was completed in October 1938 and after the ground tests it was first flown in February 1939. Due to the insufficient engine power, resulting from a faulty cooling system, the aircraft developed a maximum speed of only $420-430 \mathrm{kph}$ (only as much as PZL P-24 with a fixed undercarriage), and was characterized by a worse agility in comparison to the aircraft with the Pulaski wing.

In the first half of 1939, the second prototype was completed, which during the flight tests in August reached the maximum speed of $480 \mathrm{kph}$ (in one of the flights even $505 \mathrm{kph}$ ) (Table 1). 
Table 1. Tactical and technical data of the PZL P-50 Jastrzq $[1,5]$

\begin{tabular}{|c|c|c|c|}
\hline $\begin{array}{c}\text { Tactical and } \\
\text { technical data }\end{array}$ & P-50A & P-50B & I prototype \\
\hline Aerodynamic system & $\begin{array}{l}\text { single-seat self-supporting } \\
\text { low-wing metal structure }\end{array}$ & $\begin{array}{l}\text { single-seat self-supporting } \\
\text { low-wing metal structure }\end{array}$ & $\begin{array}{l}\text { single-seat self-supporting } \\
\text { low-wing metal structure }\end{array}$ \\
\hline Power unit & $\begin{array}{l}\text { Engine PZL Bristol } \\
\text { "Merkury" VIII max power } \\
610 \mathrm{~kW}(830 \mathrm{KM}) \\
\text { three-blade metal adjustable } \\
\text { propeller }\end{array}$ & $\begin{array}{l}\text { Engine Bristol "Taurus" III } \\
\text { power max } 840 \mathrm{~kW} \text { (1145 KM), } \\
\text { three-blade metal adjustable } \\
\text { propeller }\end{array}$ & $\begin{array}{l}\text { Engine PZL Bristol } \\
\text { "Merkury" VIII power max } \\
610 \mathrm{~kW}(830 \mathrm{KM}) \\
\text { three-blade metal } \\
\text { adjustable propeller } \\
\text { Hamilton-Standard }\end{array}$ \\
\hline Landing gear & $\begin{array}{l}\text { two-legged retractable Dowty } \\
\text { main undercarriage and tail } \\
\text { wheel }\end{array}$ & $\begin{array}{l}\text { two-legged retractable Dowty } \\
\text { main undercarriage and tail } \\
\text { wheel }\end{array}$ & $\begin{array}{l}\text { two-legged retractable } \\
\text { Dowty main undercarriage } \\
\text { and tail wheel }\end{array}$ \\
\hline Armament & $\begin{array}{l}4 \text { machine gun PWU wz. } 36 \\
\text { caliber } 7,9 \mathrm{~mm} 100 \mathrm{~kg} \text { bomb }\end{array}$ & $\begin{array}{l}4 \times \text { machine gun PWU wz. } \\
36 \text { caliber } 7,9 \mathrm{~mm} 2 \times \text { gun } \\
\text { cal. } 20 \mathrm{~mm} 300 \mathrm{~kg} \text { bomb }\end{array}$ & - \\
\hline Surface area & $19,4 \mathrm{~m}^{2}$ & - & $19,4 \mathrm{~m}^{2}$ \\
\hline Wingspan & $9,7 \mathrm{~m}$ & - & $9,7 \mathrm{~m}$ \\
\hline Lenght & $7,7 \mathrm{~m}$ & - & $7,7 \mathrm{~m}$ \\
\hline Height & $2,7 \mathrm{~m}$ & - & $2,7 \mathrm{~m}$ \\
\hline Net weight & - & - & $1900 \mathrm{~kg}$ \\
\hline Total weight & - & - & $2400 \mathrm{~kg}$ \\
\hline Max speed & $500 \mathrm{~km} / \mathrm{h}$ & - & $430 / 480 / 505 \mathrm{~km} / \mathrm{h}$ \\
\hline Rate of climb & - & - & $11 \mathrm{~m} / \mathrm{s}, 7 \mathrm{~min}$ na $5000 \mathrm{~m}$ \\
\hline Flight ceiling & - & - & $9000 \mathrm{~m}$ \\
\hline Range & - & - & $750 \mathrm{~km}$ \\
\hline
\end{tabular}


Figure 3. The first serial copy of the PZL-50 Jastrzqb plane in the state of decay — occupied Warsaw in winter 1939/1940 [8]

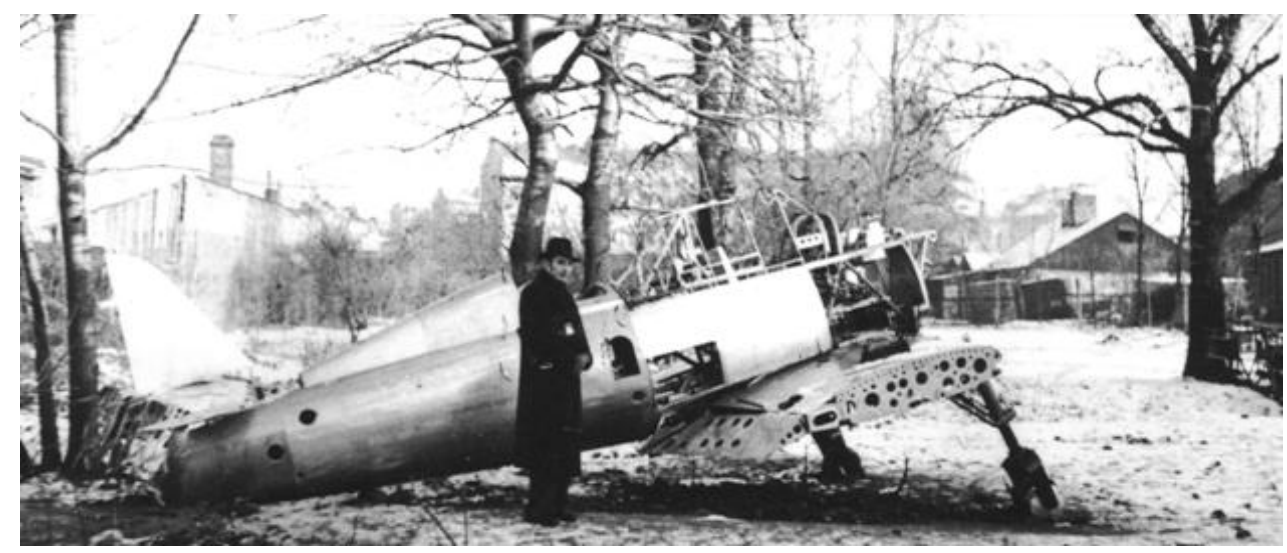

\section{A multidisciplinary research project}

In recent years, PZL Mielec employees have made a replica of the PZL-37B Łoś bomber as part of their volunteer work. The replica was added to the collection of the Polish Aviation Museum in Cracow and became one of the most impressive exhibits (Fig. 4).

Figure 4. Replica of PZL-37B Łoś bomber during

its presentation in Mielec in September 2012 [17]

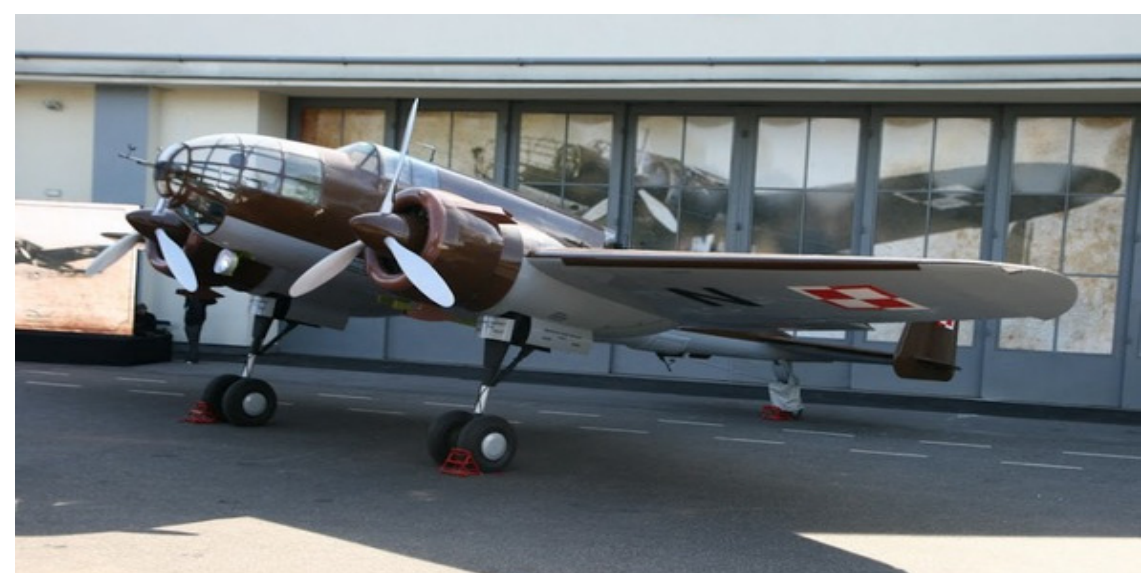


In 2015 , one of the two existing in the world copies of the French Caudron CR-714 Cyclone fighter aircraft was borrowed from Finland to be exhibited in the Polish Aviation Museum in Krakow. On such planes, in May and June 1940, in defense of Paris and the estuary of the Seine, the only Polish compact fighter's formation fought - Groupe de Chasse Polonaise de Varsovie GC 1/145. The plane arrived incomplete and thanks to ATMAT the cower engine, propeller and propeller spinner were printed (Fig. 5).

Figure 5. French fighter plane Caudron CR-714 Cyclone with added parts made by large format 3D printing technology: full cover engine, front the radiator and three-blade propeller spinner(Photo: Jakub Link-Lenczowski via [8])

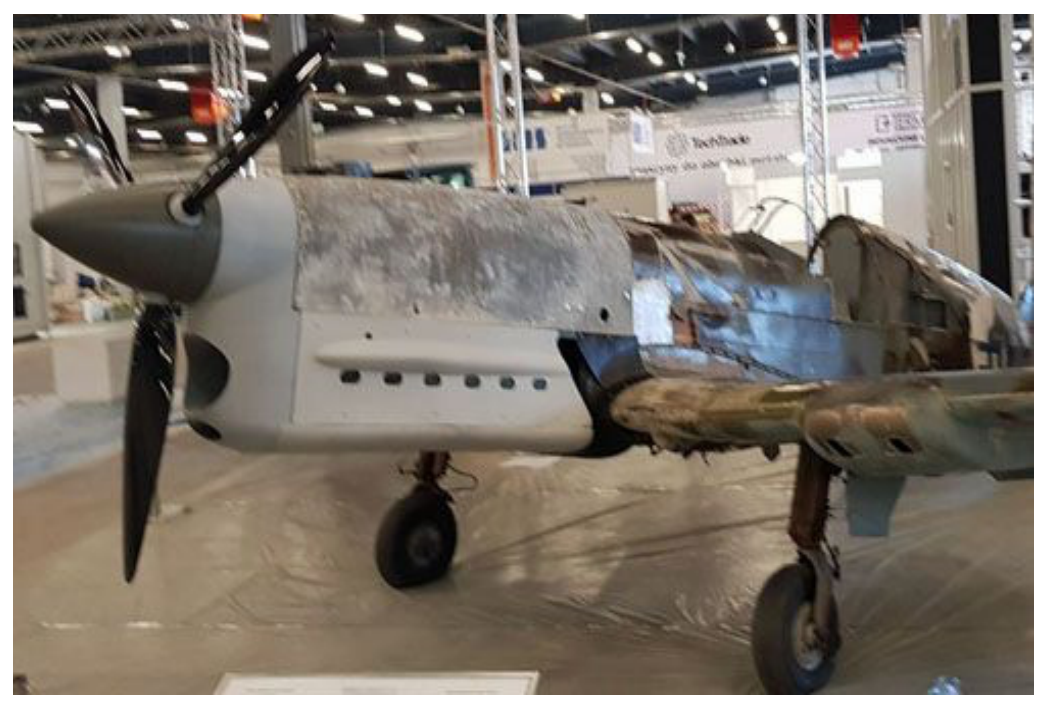

On the basis of the above experience, the approach to the topic of recreating the PZL-50 Jastrząb fighter plane can be preliminarily defined. Due to the lack of sufficient data,

a multidisciplinary research project is proposed to be launched in order to reconstruct the geometry of the airframe, basic design documentation, aerodynamic analysis and flight mechanics, and to determine the performance of the aircraft. The project should be carried out with the help of the best known photographs of the prototype, memories of people connected with production and research in flight, 
known geometry and performance of the power unit, probable similarity of the pilot's cabin to the cabin of the P-24 aircraft, known technology of making metal structures of aircraft in PZL plants at that time, etc.

In the cases of complete lack of information, strength, aerodynamic and performance analysis can be used in accordance with the art of engineering, taking into account the state of the art from the late 1930s. For example, knowing the level of metallurgy of aircraft alloys from that period, it is possible to initially determine the strength properties of sheets and pipes used in aircraft structures. Some of the data can be obtained from abroad. For example, in February 1939 the first prototype of the Jastrząb was shown to the Italian Foreign Minister. There are known 2-3 photos from this presentation. However, maybe there is more data in the Italian archives, including photographs and notes from the show? The retractable undercarriage was supplied by the British company Dowty. Maybe they have documentation of this undercarriage in their archives? The engine was supplied by the British company Bristol and implemented into serial production in PZL W-1 works. Maybe there is documentation of this type of engine? And so on, in terms of weapons, pneumatics, cabin equipment. A lot of work can be done with the help of students and doctoral students. However, some research requires the involvement of various research institutions and the use of their measurement equipment and software for various calculations and simulations [20].

According to the crowdsourcing rules it is desirable to have a "long tail" in the community, i.e. a group of fans/ enthusiasts who will always support the project. Obvious candidates to become members of the "long tail" in the Internet community are students of aviation faculties of national universities. They can support the project by directly carrying out design and computational tasks, simulations and visualizations, 3D models and preparing data for $3 \mathrm{D}$ printing, etc.

One can not only limit oneself to engineering students, but also get interested in the project, e.g. history students. There are also those who want to specialize in the history of aviation technology development. Their participation in the works will certainly bear fruit in the form of greater integration of the scientific community and will allow to establish new acquaintances and expand interdisciplinary knowledge. 
The turmoil on the domestic and perhaps also international student forums may attract foreign students to cooperate with us. However, it should be noted that it is necessary to verify students participating in the project because of the risks associated with trolling, impersonating someone, hating, etc. activities that disorganise the work, demotivate participants and cause a loss of confidence in the project and its participants.

The work can be divided into the following stages, but if possible they can be carried out in parallel.

\section{Stage}

At the beginning, the community may collect all data about the PZL P-50 Jastrząb aircraft, design and production technologies in Polish Aircraft Factory (PZL), engine and undercarriage, etc.

\section{Stage}

The next step is to analyze the geometry, masses and performance and, on this basis, to determine the strength requirements for the airframe. It is necessary to create a spatial model with identifiable assemblies, subassemblies and parts. Each element is important in the process of reproducing the historical structure (Fig. 6).

Figure 6. Computer 3D model of the PZL P-50 Jastrzqb [6]

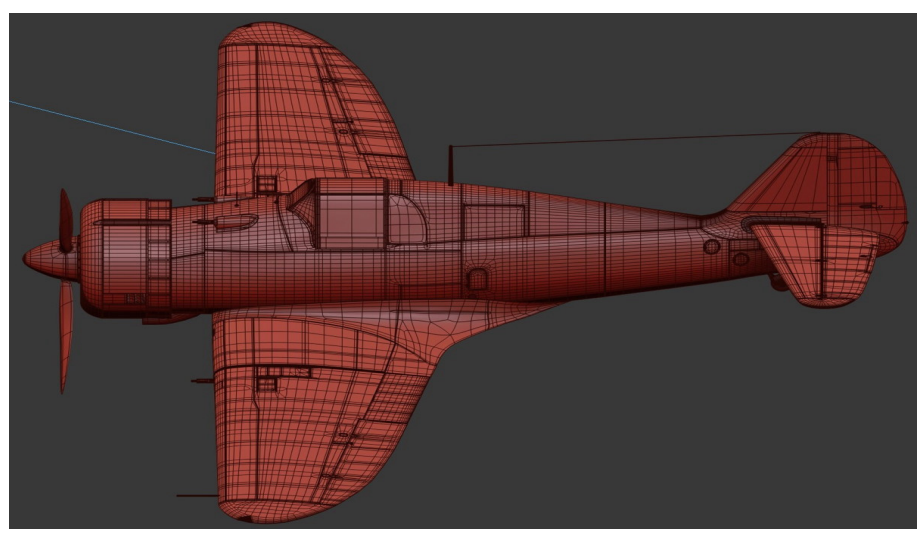




\section{Stage}

Based on the Jastrząb's spatial model, the Institute of Aviation can perform virtual aerodynamic blows using Fluent software. Using other types of software, stability and steering analyses can be performed to obtain preliminary data on aircraft flight characteristics and performance.

\section{Stage}

Based on the obtained data from computer (Fluent) and tunnel tests, simulations, analyses, etc. it is possible to make a preliminary and structural design of the PZL P-50 aircraft using modern materials and based on modern manufacturing technologies. The analyses of mass and performance differences for such an aircraft using a modern power unit of similar power can be instructive.

\section{Stage}

Based on the above, it is desirable to create a dynamically similar flying model in order to verify the assumptions and preliminary verification of its flight properties (Fig. 7).

Figure 7. Dynamically similar flying model of an aircraft in the MOSUPS aircraft in the system of interconnected wings made by the MSP company within the research project of the Institute of Aviation, ITWL, Warsaw University of Technology and MSP [15]

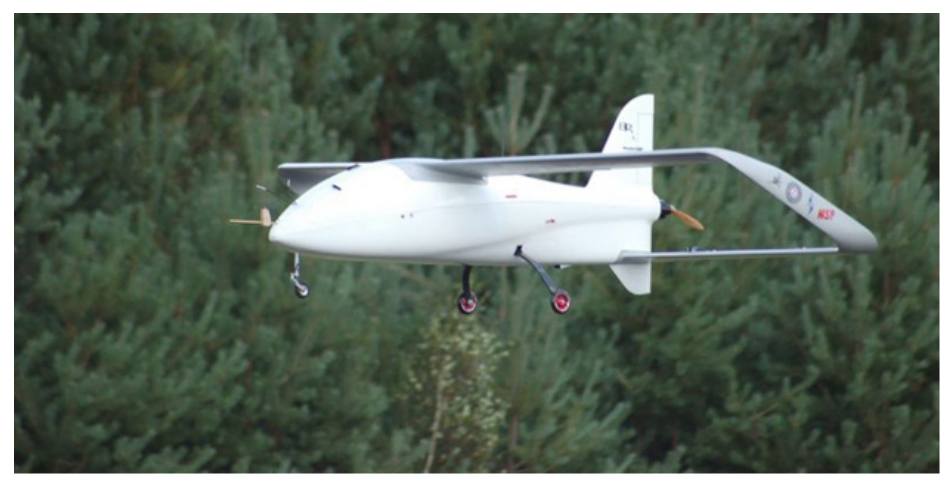




\section{Stage}

On the basis of previous work, a report summarising all the work should be drawn up and, above all, conclusions, observations and guidelines for further work should be drawn up. The above list of stages can be extended to include other valuable activities to enhance knowledge and experience among students, academics and specialists from research and development organisations.

The work carried out may be treated as a pilot programme before further similar activities, including reverse engineering of the MiG-29 aircraft, SCUD and Toczka earth to earth ballistic rockets, using the achievements of the Institute of Aviation, e.g. in the field of rocket fuels, for the benefit of the Republic of Poland's defense.

\section{Crowdsourcing (Community cooperation)}

Crowdsourcing is a new model of cooperation and money earning resulting from the development of the Internet and the emergence of a wide variety of social media, such as Facebook, Twitter, Instagram, YouTube, etc., as well as from the development of the Internet. Crowdsourcing is a digital and distributed model of production or problem solving by the Internet users, fulfilling specific goals of the organizer (companies, government non government organizations (NGO) or individuals) [11]. This is an activity that involves working with communities to achieve a specific goal by unlocking and targeting its collective potential. Crowdsourcing enables the division of work among Internet users, which can bring together a group of enthusiasts around the project and create synergy of activities.

For example, crowdsourcing monitors the state of threat of natural disasters, and when they occur, the community participates in the inventory of damages and still existing risks [9]. In 2011, the London police published videos from street cameras on the Internet to identify the perpetrators of crime, which allowed them to be captured [10]. As part of crowdsourcing, meteorological data recorded in the logbooks of ships and warships one hundred and more years ago are entered into 
digital databases. Based on this data, it is possible to reconstruct weather conditions and general climate conditions in areas where there were and still are no permanent meteorological stations (e.g. the South Pacific) [16].

In general, there is a lot of data in paper form and on photographic films, the digitalization of which will allow to build databases (big data). By using artificial intelligence and machine learning, these huge amounts of data can already be analyzed and many specialized reports can be obtained that will allow a better understanding of historical processes, including the fate of individuals. Crowdsourcing also allows you to draw on the intellectual potential of Internet users and thus solve a variety of problems. Therefore, it is possible, for example, to recruit new employees based on their previous activity and prove themselves in a crowdsourcing project [12].

Crowdsourcing usually involves rewarding co-workers, e.g. by sending them special, unavailable content (information, studies, reports, visualizations, etc.). In the case of performing certain tasks (e.g. entering meteorological data), co-workers also receive remuneration within the so-called macrowikinomy (Fig. 8).

Figure 8. Organisational diagram and dependencies within the framework of macrowikinomics [14]

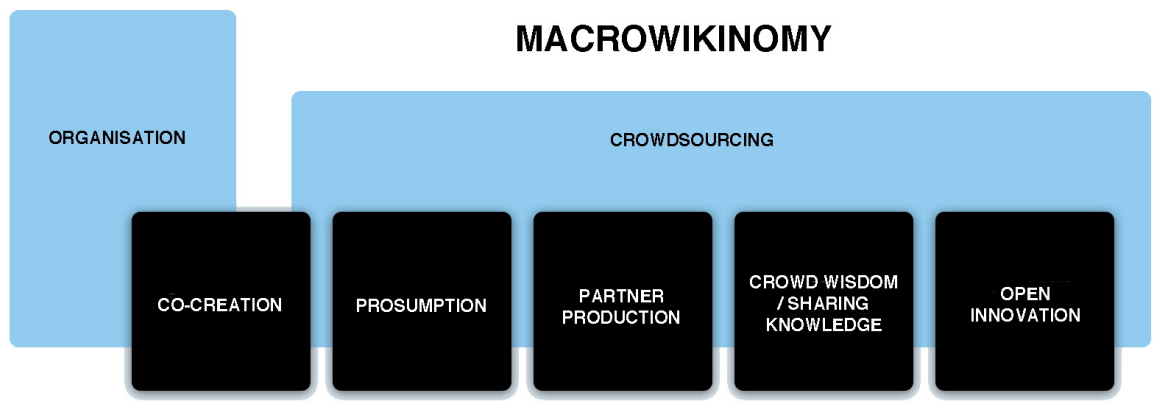

For example, dispersed micro-activities (microtasks) accelerate the search for exoplanets in the images of terrestrial and space telescopes and radiotelescopes made available by NASA to Internet users, British libraries facilitate digitalization of Shakespeare's peer letters, and the Canadian government collect statistical data needed to regulate the 
cannabis market [13]. As a result, opportunities to earn money through so-called micro-working are being developed, for example for unemployed people or those who want to earn extra money while working at home (teleworking).

Crowdsourcing assumes a different hierarchy of dependencies compared to the traditional production model (Fig. 9), because the project control center is on the network, but still there is a specific organizer, and processes are performed by the Internet community. This applies to both production and services, but above all, it works very well in the field of advertising and marketing.

Figure 9. Comparison of the traditional production model with the models resulting from the communication capabilities of the Internet, especially social media [13]

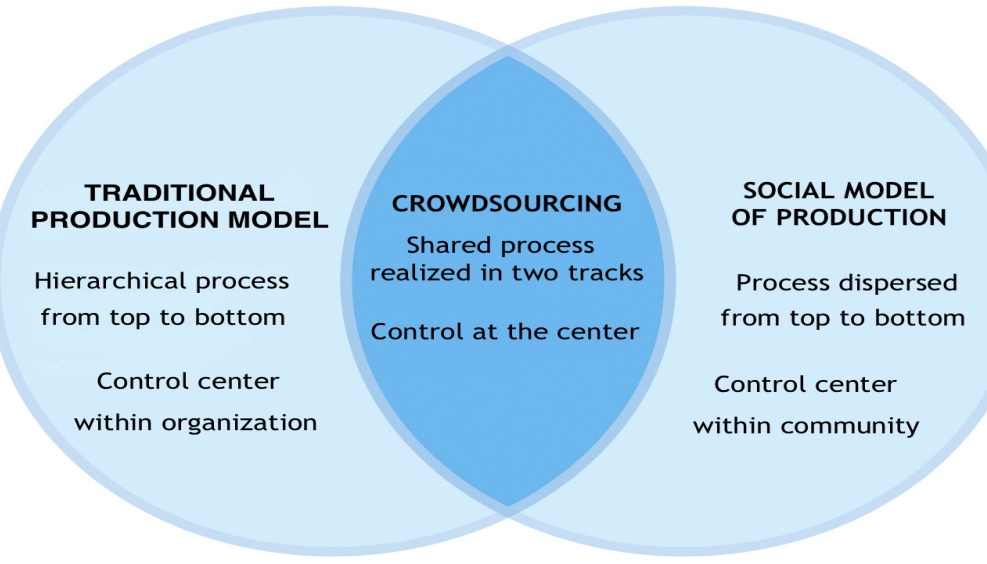

The next stage may be crowdfunding which assumes a financial contribution of people to the project. Due to their financial participation in the project, these people are also active in the field of promotion, PR and marketing. They are often hobbyists, fans and other enthusiasts.

Organizing community funding activities requires the existence of an Initiator, Work to Do and a Community to achieve Common Benefit (Figure 10). 
Figure 10. General scheme of crowdfunding and croudsourcing [13]

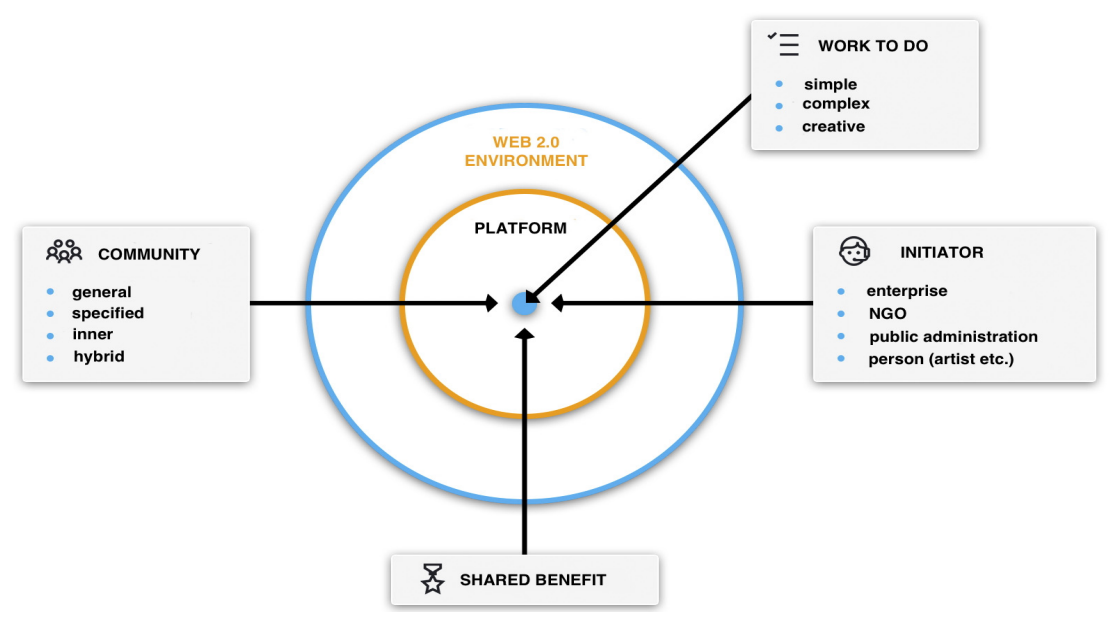

Arranging it in a logical process [13]:

1. The initiator, which can be any enterprise, non government organisation (NGO), public administration or person, has a specific goal (e.g. creating a new product, processing a large collection of data, solving a scientific problem);

2. on its basis creates the Work to Do and presents it on an Internet platform in the form of an open invitation;

3. The Work to Do is carried out (individually or in groups) by a community of random or specific Internet users in exchange for a concrete benefit (material or immaterial);

4. The initiator receives the solution or work done or merely uses the community contribution as one of the components to achieve its objective.

The niche products include numerous goods and services, the sale of which can generate a higher total income than only hits and best sellers (Fig. 11). The offer of research and development organizations is by definition niche and usually very extensive.

Institute of Aviation offers a wide range of $R \& D$ services, namely [14]: 
Figure 11. Web 2.0 business model with niche products (the so-called "long tail") according to the concept of Chris Anderson, long-term editor-in-chief of WIRED [13]

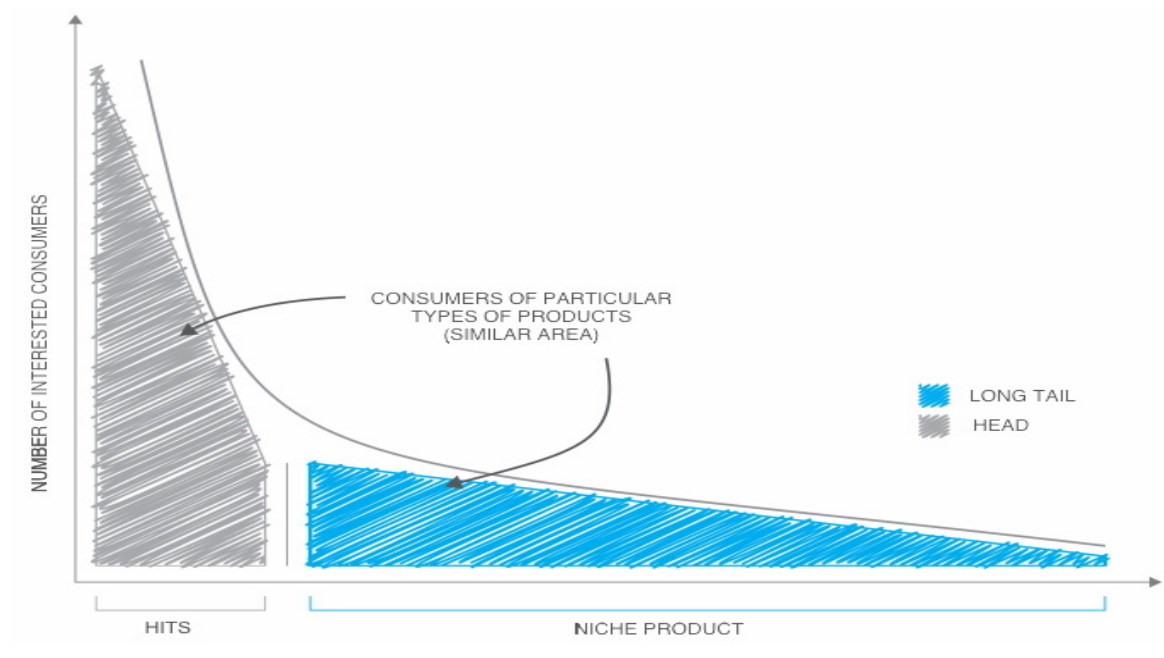

1. R\&D services;

2. laboratory tests;

3. materials and structure research within the Materials \& Structures Research Center;

4. research within the Center of New Technologies;

5. research within the Center of Space Technologies;

6. research within the Center of Composite Technologies;

7. research at the Center of Transportation and Energy Conversion.

Potential of the project as a medium for the dissemination of knowledge/science

The results of a multidisciplinary project can be successfully used in the marketing of research institutions participating in the works. The results can be presented at fairs, conferences, symposiums, seminars, etc. Many articles for trade press can be written.

The educational values of the project should not be forgotten and its results should also be presented at mass events, intergenerational 
meetings, etc. The results of the project should not be forgotten. Ultimately, a replica of the PZL P-50 Jastrząb plane would be exhibited in the Polish Aviation Museum in Krakow, but earlier it may become an exceptionally attractive exhibit during various meetings and conferences in research and development institutions participating in the multidisciplinary project and be exhibited at anniversary state ceremonies. Of course, all data from the project can be used in promotional materials published on the Internet and distributed during fairs, conferences, symposia, in the form of monographs, etc.

For example, a replica of the PZL P-50 Jastrzab can be the central point of a joint stand of research and development institutions at trade fairs in Poland and abroad. This will certainly be noted by the media accredited at these exhibitions.

However, the real novelty will be the use of crowdsourcing in marketing activities through the participation of the Internet community in the whole enterprise and its impact on others through social media activity. In order to stimulate this activity it is possible to use proven methods from social financing (crowdfunding), in which financial reward of project participants is used.

However, during the implementation of this project, we can reward participants in other ways, such as by making the content of the internal website of the project available and receiving information packages with visualizations and other interesting content. They can be co-authors of articles for scientific conferences and articles directed for publication in trade magazines, which will allow for an increase in the number of publications in a person's scientific output.

It is obvious that the participants' activity and skills in the recruitment procedures will be used to work in a scientific research organisation.

The process of reconstructing the aircraft will take a certain amount of time, so the media will be constantly informed about the progress of work and thus the next departments and laboratories of the research unit may present themselves in the form of notes from current activities, and not in the form of advertising (which may also take place at the occasion).

It should also be noted that the aging of aviation engineering staff is progressing. According to unconfirmed information, the average age of 
an engineer at Boeing is already over 55 simply because young people have many other opportunities to earn money, probably also less intellectually demanding, and they do not cling to technical and science studies. Therefore, it seems at least desirable for young people to be interested in aviation technology (science) as part of an interesting research and development project.

Promoting the technical achievements of Polish aircraft manufacturers in Poland and internationally is also useful for prestige reasons. For example, in 1945, on the order of the British Royal Air Force, the main designer of the P-50 Jastrząb aircraft, engineer Wsiewołod Jakimiuk, together with engineer Wiesław Stępniewski, constructed the DHC-1 Chipmunk school plane which was produced in 1280 copies. Jakimiuk also had a significant influence on the construction ofthe aircraft de Havilland DHC-2 Beaver, and DHC-3 Otter, and in 1962-1966, he became one of the five commercial directors of the supersonic French-British aircraft Concorde.

\section{Summary}

Taking care to preserve the scientific and technical achievements of past generations is a necessity if we want to preserve national identity, including the development of technical thought. Knowledge and experience gained by ancestors significantly facilitate further economic development of the country. Pride in the achievements of previous generations generates a positive interest in science and technology among children and adolescents, which translates into a greater number of people studying engineering sciences and thus greater rationality in social life. Introducing wider groups of the society to the norms and regulations of aircraft construction will allow to educate the society technically [18].

In the proposed project, work can be undertaken on the construction of a flying replica of the PZL-50 Jastrzab airplane, e.g. as part of the portal for financing scientific work [16]. It would certainly be one of the stars at every air show in Poland and abroad. The paved paths associated with the reconstruction of a historical aircraft will allow us to undertake 
further projects aimed at bringing back to existence the preserved aircraft structures. Many Polish structures can be mentioned here, but also those used by Polish aviation, both military and civil. Historical research conducted in parallel will allow to fill in many white spots related to Polish aviation.

The use of social media will allow to increase the impact of the marketing of the research and development organization and popularization of engineering and scientific fields of study, and thus the introduction to the job market in the general aviation technology of new people who will be passionate about their fields of study and work.

\section{Bibliography}

[1] Glass A., Polskie Konstrukcje Lotnicze 1893-1939, Wydawnictwa Komunikacji i Łączności, 1976.

[2] Malak E., Prototypy samolotów bojowych Polska 1936-1939, Wydawnictwo Uniwersytetu Wrocławskiego, 1990.

[3] Malak E., Prototypy samolotów bojowych i zaktady lotnicze Polska 1930-1939, Instytut Wydawniczy ERICA, 2011.

[4] Malak E., DZIEŁO GENERAEA RAYSKIEGO Technika i zarzadzanie, Instytut Historii Nauki PAN, 2015.

[5] Cynk J., Polish Aircraft 1893-1939, Putnam \& Company, 1971.

[6] https://max3d.pl/forums/topic/100461-pzl-p-50-a-jastrząb/, (member: kliment woroszyłow).

[7] Mazur W., Projekty i prototypy samolotów myśliwskich, Cykl: Wielki Leksykon Uzbrojenia Wrzesień 1939, Nr 73, Wydawnictwo Edipresse, 2015.

[8] Agencja Lotnicza Altair, www.altair.com.pl

[9] Bodnar M., Crowdsourced Damage Mapping for Disaster Emergency Response - the 2015 Nepal Earthquake Case Study, United Nations/India Workshop on the Use of Earth Observation Data in Disaster Management and Risk Reduction: Sharing the Asian Experience, 2016.

[10] Yang Hui J., Crowdsourcing for National Security, Policy Report, Centre of Excellence for National Security (CENS), S. Rajaratnam School of International Studies (RSIS), Nanyang Technological University (NTU), 2015.

[11] Brabham D. C., Crowdsourcing, The MIT Press Essential Knowledge Series, 2013.

[12] Green A., de Hoyos M., Barnes S-A., Baldauf B., Behle H., CrowdEmploy Crowdsourcing Case Studies: An Empirical Investigation into the Impact of Crowdsourcing on Employability, European Commission, Joint Research Centre, Institute for Prospective Technological Studies, JRC Technical Reports, 2013.

[13] WeTheCrowd, www.wetehcrowd.pl 
[14] Kowalska M., Crowdsourcing internetowy - Pozytywny wymiar partycypacji spotecznej, Wydawnictwo SBP, 2016.

[15] Łukasiewicz Research Network — Institute of Aviation, www.ilot.edu.pl

[16] Scienceship, www.scienceship.com

[17] Muzeum Lotnictwa Polskiego, www.muzeumlotnictwa.pl

[18] Szafran K., Michalczyk M. (2018) Various types of the rotorcraft design in the context of aerospace regulations'. Transaction of the Institute of Aviation. ISSN 0509-6669 Nr 1 (250). pp. 142-149.

[19] Szafran K. (2017) TRAINEESHIPS INDUSTRIAL AND PROFESSIONAL PRACTICE AS EFFECTIVE MECHANISM OF MARKETING OF THE SCIENTIFIC AND RESEARCH INSTITUTE. DOI: 10.14611/minib. 23.03.2017.02 MINIB, Vol. 23, Issue 1, p. 21-36.

[20] Szafran K., Kramarski I., (2018) Fatigue Degradation of the Structure of Parachute Systems. Fatigue of Aircraft Structures. The Journal of Institute of Aviation. ISSN 2081-7738, eISSN 2300-7591, Vol. 2018 pp. 93-103.

Doctor of Science Krzysztof Szafran - Is an employee of the Institute of Aviation since 1980. Obtained the title Doctor of Science in the Construction and exploitation of machines is the result of scientific studies conducted at the Institute of Aviation. Author of more than 80 papers published in journals and monographs, including as the creator of the six patents the Republic of Poland and utility model. Design solutions contained in the patents have been implemented for the production of special means of transport. He leads as a promoter of dissertations, theses and engineering. Participant congresses and symposia related to flight safety, aerodynamics, aircraft and operation of transport systems. The teaching activities was a teacher and creator of software engineering practices and industrial internships. Interests - aerospace safety, aerodynamics, ballistics and dynamics of aircraft, hovercraft, airship design - technology, ekranoplans. Reviewer of scientific papers, projects, monographs and publications in scientific journals.

Ireneusz Kramarski - Is a graduate of the Faculty of Power and Aeronautical Engineering of the Warsaw University of Technology, Poland. He is a engineer with speciality of design and construction of aircrafts, parachutes and airships. He is a author of more than 10 papers presented on conferences and published in science journals. He is also a author of a number of aviation history's books. He has a knowledge and experiences from a number of designs and modification works referred to personnel, troops and cargo parachutes and aerodecelerators for warplane's landing runs. Interests: parachutes, aerodecelerators, aerospace safety, aerodynamics, ballistics and dynamics of descending objects, hovercraft, airship design.

$\mathrm{He}$ is a doctorate candidate working on dissertation on the subject of aerodecelerators and dissipation energy systems designed for atmospheric descending objects. 